International Journal of Current Advanced Research

ISSN: O: 2319-6475, ISSN: P: 2319 - 6505, Impact Factor: SJIF: 5.995

Available Online at www.journalijcar.org

Volume 6; Issue 5; May 2017; Page No. 3599-3600

DOI: http://dx.doi.org/10.24327/ijcar.2017.3600.0326

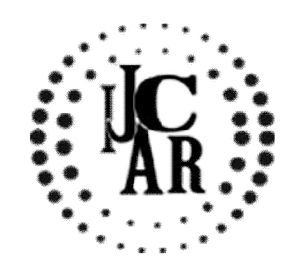

Research Article

\title{
COMPARISON OF SALIVARY NEUTROPHILS AMONG SMOKERS AND NON SMOKERS WITH CHRONIC GINGIVITIS
}

\author{
Manoj Kumar K.R and Thamarai Selvan
}

Deparment of Periodontics, Saveetha Dental College, Chennai

\begin{tabular}{|c|c|}
\hline 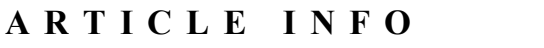 & A B S T R A C T \\
\hline $\begin{array}{l}\text { Article History: } \\
\text { Received } 17^{\text {th }} \text { February, } 2017 \\
\text { Received in revised form } 12^{\text {th }} \text { March, } 2017 \\
\text { Accepted } 2^{\text {nd }} \text { April, } 2017 \\
\text { Published online } 28^{\text {th }} \text { May, } 2017 \\
\text { Key words: } \\
\text { Salivary Neutrophils, Chronic Gingivitis }\end{array}$ & $\begin{array}{l}\text { Aim of this is to evaluate salivary neutrophils and compare its count in smokers and non } \\
\text { smokers chronic gingivitis attending the department of periodontics in saveetha dental } \\
\text { college. Early studies revealed that saliva from patients with periodontitis contained a } \\
\text { greater number of leukocytes than saliva from healthy patients. The rate at which } \\
\text { neutrophils migrate through the gingival sulcus into the oral cavity [i.e. the orogranulocytic } \\
\text { migratory rate (OMR)] is increased in the presence of gingival inflammation. The OMR } \\
\text { also correlates with increased pocket depth and the gingival index. Studies were conducted } \\
\text { using neutrophil quantification to assess gingival/periodontal disease activity and } \\
\text { effectiveness of therapy.Cigarette smoking influences gingival/periodontal disease through } \\
\text { systemic influences like decreased phagocytosis by both oral and peripheral neutrophils and } \\
\text { reduced antibody production. Other effects include vasoconstriction caused by nicotine as } \\
\text { well as decreased oxygen tension, which may create a favorable sub-gingival environment } \\
\text { for colonization by anaerobic bacteria. Smokers tend to have greater numbers of deeper } \\
\text { periodontal pockets and greater probing pocket depth (PPD). This analyses primarily } \\
\text { evaluates the salivary neutrophils with the presence of chronic gingivitis in smokers as well } \\
\text { as non smokers. }\end{array}$ \\
\hline
\end{tabular}

Copyright $(2017$ Manoj Kumar K.R and Thamarai Selvan. This is an open access article distributed under the Creative Commons Attribution License, which permits unrestricted use, distribution, and reproduction in any medium, provided the original work is properly cited.

\section{INTRODUCTION}

Neutrophils are the sentinels of the oral immune system (Bender et al., 2006) ${ }^{\mathbf{1}}$. They are the most abundant white blood cell in our body, accounting for up to $70 \%$ of circulating leukocytes. Neutrophils are produced in the bone marrow at the rate of 60 billion cells/day. This high rate of production is essential as these cells have a short circulation half life of about 10 hours and survives up to 48 hours additionally once they reach infected or damaged tissues. Monitoring neutrophil levels using complete blood counts is used to determine the presence of undiagnosed infections, to determine if a patient is able to produce normal innate immune response, and to verify that a patient is able to produce a sufficient supply of these key microbe killing cells ${ }^{2}$. This is particularly important when planning any dental treatment in patients who have undergone any recent treatment or are taking any medications that may impact their bone marrow or who may have genetic diseases that impact on the hematopoietic system ${ }^{3}$.

The human mouth has a constant bacterial presence that is kept under control, in large part, by a continual influx of neutrophils from the surrounding periodontal tissues.

*Corresponding author: Manoj Kumar K.R

Deparment of Periodontics, Saveetha Dental College, Chennai
Neutrophils carry out a discrete set of processes that allow them to migrate from the blood into the specific infected tissues where they are able to phagocytose the invading bacteria and kill them utilizing enzymes and specialized killing machinery that generates oxygen radicals. Strong evidence demonstrates, significant portion of the inflammatory mediated detorioration of the tooth supporting tissues (periodontium) that occurs as a result of collateral damage caused by the enzymes released by hyperactive neutrophils as they attempt to contain the bacterial infection. In fact neutrophil collagenase (matrix metalloproteinase 8 [MMP-8]), released during periodontal infections is one of the major enzymes responsible for degradation of tooth supporting bone and ligament ${ }^{4}$.

Inflammation of the marginal gingival tissues is a common condition and its extent and severity could be variable. This condition which is known as gingivitis can be modified by systemic and local influences and is plaque induced. It can be reversed if improved oral hygiene measures are introduced ${ }^{5}$. Chronic periodontitis is a result of a response of the host to bacterial aggregations on the tooth surfaces. The outcome of this is an irreversible destruction of the connective tissue attachment, which results in periodontal pocket formation and eventual loss of alveolar bone ${ }^{6}$. Smoking has been reported as a major risk factor for periodontal disease. Studies also have demonstrated decrease in bleeding on probing and decreased 
inflammatory response among smokers, which has been attributed to the alterations in gingival microvasculature, gingival epithelium ${ }^{7}$. Previous investigation which revealed, vascular and epithelial changes have been studied in the gingival tissues of smokers suffering from periodontitis and compared with healthy periodontium of non smokers ${ }^{8}$. Inflammation can cause vascular and epithelial changes in the gingiva on its own in the absence of smoking 9 . Hence, in the present investigation, an attempt is made to study and to compare the neutrophil count in the gingiva of smokers and non smokers suffering from generalizedchronic gingivitis ${ }^{7,10}$.

\section{MATERIALS AND METHOD}

Out patients reported to Saveetha dental college and are allotted to the department of periodontics. Total number of 65 Patients are screened for presence of chronic gingivitis out of which 50 patients willing for the study are randomized in the group of two as smokers \& non smokers. Saliva sample is then collected from them with their valid written consent. Samples collected [in a uricol $(10 \mathrm{ml})$ each] is then stored under proper biological environment and sent for quantitative neutrophil analysis. Values obtained from the analyses is then tabulated and derived with proper statistical significance for obtaining final results.

\section{RESULTS AND DISCUSSION}

\begin{tabular}{cccc}
\hline & Non Smokers & Smokers & P value \\
\hline $\begin{array}{c}\text { Neutrophil Count } \\
{[\text { MEAN } \pm \text { SD] }}\end{array}$ & $0.20 \pm 0.56$ & $1.44 \pm 1.87$ & $0.00 *$ \\
\hline
\end{tabular}

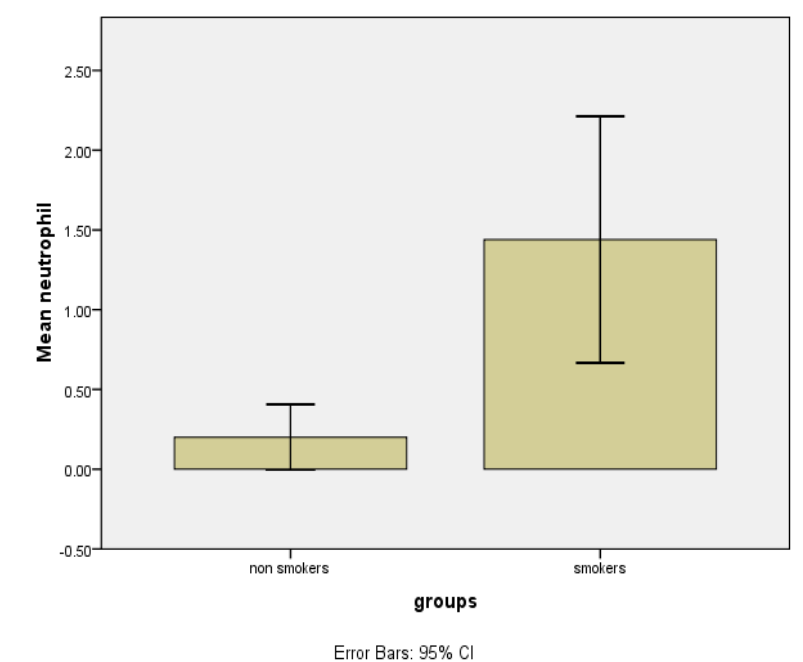

Results from this study shows that out of 50 patients, 25 are non smokers and 25 are smokers in which smokers had high prevalence of increased neutrophil count when compared with non smokers, but previous study involving smokers with gingival/periodontal disease revealed that neutrophil count might get decreased due to the cause that, in smokers -OMR (orogranulocytic migratory rate) is reduced as a result of vasoconstriction due to tobacco which hinders the migration of leukocyte at that site. This study also revealed that heavy smokers may have less neutrophil count than moderate and less smokers since our study involved only last two groups of smokers.

\section{CONCLUSION}

From our study we conclude that smokers had an increase in quantity of salivary neutrophils compared to non smokers with chronic gingivitis. Further studies are needed to assess the quality of neutrophils in saliva between smokers and non smokers.

\section{Reference}

1. Bender, J.S., H. Thang, and M. Glogauer. 2006. Novel rinse assay for the quantification of oral neutrophils and the monitoring of chronic periodontal disease. J Periodontal Res. 41:214-20.

2. Defraia, E., and A. Marinelli. 2001. Oral manifestations of congenital neutropenia or Kostmann syndrome. J Clin Pediatr Dent. 26:99-102.

3. Glauser, M.P. 2000. Neutropenia: clinical implications and modulation. Intensive Care Med. 26 Suppl 1:S103-10.

4. McCulloch, C.A., P. Birek, C. Overall, S. Aitken, W. Lee, and G. Kulkarni. 1990. Randomized controlled trial of doxycycline in prevention of recurrent periodontitis in high-risk patients: antimicrobial activity and collagenase inhibition. J Clin Periodontol. 17:616-22.

5. Martha E. Nunn. Understanding the etiology of periodontitis-an overview of periodontal risk factors. Perio 2000. 2003; 32: 1, 11-23.

6. Brown LJ, Oliver RC, Loe H. Periodontal diseases in the U.S. in 1981: prevalence, severity, extent, and role in tooth mortal- ity. J Perio 1989; 60; 7: 363-70.

7. Holm G, Johnson GK, Hill M. Cigarette Smoking and the Periodontal Patient. J Periodontol. 2004; 75:196209.

8. Palmer RM, Wilson RF, Hasan AS Scott DA. Mechanisms of action of environmental factorstobacco smoking. J Clin Perio 2005; 32: 180-195.

9. Banoczy J, Gintner Z, Dombi C. Tobacco use and oral leu- koplakia. J Dent Educ 2001; 65: 322-6.

10. Ismail AI, Burt BA, Eklund SA. Epidemiologic patterns of smoking and periodontal disease in the the United States. JADA 1983; 106: 617-623.

\section{How to cite this article:}

Manoj Kumar K.R and Thamarai Selvan (2017) ' Comparison Of Salivary Neutrophils Among Smokers And Non Smokers With Chronic Gingivitis', International Journal of Current Advanced Research, 06(05), pp.3599-3600. DOI: http://dx.doi.org/10.24327/ijcar.2017.3600.0326 